\title{
From the Qualities of Products to the Qualities of Relations: Value Conventions in the Solidarity Economy in Sicily
}

\author{
Mihai Varga
}

\begin{abstract}
This article explores the "quality battlefield" in the food economy - the dispute over value conventions between mainstream business actors and alternative food networks. It shows how actors in one particular alternative network - the solidarity economy - shift such notions from product qualities to the qualities of relations in production. Opposing the standardized criteria characterizing private certification schemes and organic certification, they struggle to establish the value of their products by creating and circulating verifiable stories proving their involvement in the solidarity economy. These stories further emphasize the distance to standard business motivations, for instance by accentuating the cooperative rather than competitive relations with other producers. The article illustrates the features and tensions of value conventions in alternative food networks by contrasting actors in mainstream agriculture with an expanding organization of agricultural producers adhering to solidarity economy and operating in the grocery sector in Sicily, Italy.
\end{abstract}

Key words: alternative food networks; solidarity economy; value conventions; organic certification; citrus; Sicily

\section{Introduction}

The rise of the "corporate-environmental food regime" (Friedmann 2005) saw a world food economy increasingly dominated by large agribusinesses and retail chains, setting up certification schemes raising the capital-intensity of production while promising consumers high

Mihai Varga, Institute for East-European Studies, Freie Universität Berlin, Garystr. 55,14195Berlin,0049(0)30-838-53381,mihai.varga@fu-berlin.de

(C) 2019 Author

LiU Electronic Press, DOI 10.3384/VS. 2001-5992.196163

http://valuationstudies.liu.se 
environmental and safety standards. Small farmers face unprecedented levels of "concentration" (Marsden and Morley 2014: 6) of large agribusiness and retail chains around private certification schemes such as GlobalGAP (Global certification of Good Agricultural Practices). Moreover, small farmers in Europe saw between 1950 and 1990 an intensifying "price-cost squeeze" on farms due to increases in monetary costs of external inputs and more expensive technologies, further aggravated from the 1990s on by costs due to the growing concern for the environment, animal welfare, and food safety (van der Ploeg et al. 2000: 395). A further challenge to small farmers is the aggregation taking place not only around certification schemes (uniting agribusinesses, producers, transporters, and retailers) but also within commodity chains (Vorley 2007; Lee et al. 2012; Gereffi 2014; Varga 2015): power within chains can be highly skewed toward various intermediaries such as processors and wholesalers, to the detriment of small producers. Thus to the extent that they need or wish to enter certification schemes, they enter on terms developed by retailers and enforced by wholesalers and processors.

Criticism over trends in the global food economy and the effects of industrial agriculture on the environment, as well as rising consumer anxiety over food scares have allowed the emergence of alternatives opposing the conventional sector by using notions of quality, organic farming, or the importance of the origin of products. In response, retailers and large agribusiness have embarked on a process of mainstreaming, understood as the appropriation by the largest players of values prevalent in alternative food production (Ward et al. 2008). Driven largely by retail chains, the mainstream has thus partly incorporated organic farming, developed certification schemes promising the traceability of products, and rather than invest in production increases, has triggered a "quality turn" restructuring the global agro-food system (Wilkinson 2002). Thus, conventional and alternative systems clash in a "quality battlefield" (Sonnino and Marsden 2006), in which the various sides continuously deepen and expand the meanings of quality, although some have doubted that alternative food networks (AFNs) can indeed maintain their alterity in this "battlefield" (Goodman et al. 2012).

Many of the concepts developed to capture the boundaries of AFNs - such as most notably quality - have indeed been "negotiable and contested", and "open for interpretation and appropriation" (Sonnino and Marsden 2006: 184). But more recent AFNs such as the Slow Food, Transition Town movement, and the solidarity economy are intensifying what could be called the relational or "civic" component of building value, in ways that signal further distancing from an economy perceived to be dominated by the profit motive: Rather than further particularize their products, they shift the debate away from the material qualities of products to the qualities of producers in the 
sense of the relationships that these maintain with communities, business partners, workers, and customers.

This debate - as well as the broader discussion about the "quality battlefield" - should be relevant to valuation studies and the topic of how markets develop and diversify "reflexively" (Callon et al. 2002), for instance through the market actors' struggle to "accommodate a wide variety of value registers" (Helgesson and Kjellberg 2013). Such value registers are not just derived from an economic logic centered on monetary costs, but transcend divisions between the economic and the social, often supporting or even conditioning from outside the market realm the involvement of actors in the economy (Zelizer 1978). This article advances the argument that while the emphasis on "relations" is a recurring motif in these movements, including the solidarity economy, little is known about how such distancing from mainstream businesses - from quality to "relations" - works in practice. The article argues of the example of solidarity economy that such distancing is often difficult and contested. Rather than through the development of standardized criteria, in the case of the solidarity economy distancing works through verifiable stories about concrete actions, stories that are then circulated through consumer networks.

The argument proceeds as follows. The second section discusses from the perspective of convention theory the literature on AFN. It introduces so-called "civic" networks such as the solidarity economy, defined more through the network of members than only through product characteristics. The section continues with a background description of Sicily's citrus sector; it argues that the sector has seen ever since the 2000s a rise of retailer-led commodity chains allowing wholesalers to amass unprecedented power over small producers. Wholesalers do not just control market channels to which they only allow the larger producers, but they also actively engage in their own valuation attempts. The third section shows how against this background of consolidating wholesaler presence, farmers in the solidarity economy develop alternative notions of value. Solidarity economy networks represent a venue in which farmers can build a reputation that serves as a valuation tool for their products. They build such reputations by circulating stories of their involvement in the solidarity economy and of attachment to values that are distinct from the quality of products, such as fair competition and decent working conditions, or the inclusion of disadvantaged groups in production processes. The article concludes with discussing how movements such as the solidarity economy have changed the grounds for valuing products in AFN. 


\section{From distinct notions of quality to distinct forms of valuation}

The shift away from the material properties of products to the relations that their production and consumption engender has been seen as a change in conventions regarding the value of products. While valuation can be seen as a very general process of "bringing order to mere 'differences'” (Patrick Aspers cited in Kjellberg et al. 2013: 17), it also refers to a more specific "device for the justification of prices" (Boltanski and Esquerre 2014: 21). Studies of AFN have approached differing constructions of value by building on convention theory and its "orders of worth" (Wilkinson 1997) and especially on the idea that there is "a plurality of modes of legitimate evaluation" (Boltanski and Thévenot 2000: 218). Consequently, studies of AFN distinguished a plurality of value conventions. These include "industrial" or "commercial" notions of price and standardized quality constructs in the conventional system; "domestic" conventions regarding quality constructs stressing tradition and place or the traceability of products; and "civic" conventions regarding "social justice" and "environmental sustainability" in AFN (Goodman and Goodman 2009).

The "civic" component in alternative networks manifests itself in these networks' emphasis on relations in justifying the value of products, for instance, in terms of how producers treat competitors, workforce, and disadvantaged groups. Whether food networks pursuing such civic valuation will indeed resist the conventional sector and truly represent an alternative to it is still an open question (Goodman and Goodman 2009); but more recent research has provided insights into some of the other ways in which civic networks differ from the initiatives preceding them. They have been for instance seen as "movements" (Holt-Giménez and Shattuck 2011) or as "political-ecological networks" (Brunori et al. 2011; Goodman et al. 2012: 127; Grasseni 2014: 188), that is as entities that develop a far deeper criticism and rejection of existing "food regimes" than the cases that preceded them, such as organics or Fairtrade initiatives. They are largely defined by the network of their members, both consumers and producers, "engaging together in new food citizenships" (Renting et al. 2012: 292). Such hybrid networks of producers and consumers offer participating farmers access to finance (Grasseni 2014), less complicated logistics (as they are based on "private/social tools and spaces" and "bypassing middlemen"), and "avoiding unnecessary operations and materials (such as classification, packaging and conservation)" (Brunori et al. 2011: 31). The emphasis on "relations" is a recurring motif in these movements, including the solidarity economy, in Italy for instance, even giving the title to the volume edited by the national umbrella organization of solidarity economy (Tavolo RES 2010). The insistence on relations is seen as a "relational, 
responsible vision of consumer sovereignty"; a potential "alternative to neo-classical and neoliberal views" that redefines economic utility by grounding it in collective goods such as environment, equality, and democracy; and "private happiness (in terms of critical, creative fulfillment as opposed to acquisition and spending power)" (Sassatelli 2015: 483).

It was argued above that application of convention theory to food studies allowed recognizing the different value conventions distinguishing mainstream businesses from the AFN. At the same time, convention theory also states that the coexistence of different conventions in the same system is very likely, as no convention can ensure coordination of an entire system on its own (Boltanski and Thévenot 1999): thus, the fact that alternative networks develop around conventions regarding social justice, sustainability, and more recently, "relations", does not mean that cost and efficiency conventions are irrelevant for the operation of such networks. Conventions, even conflicting ones, often coexist (Lamont and Thévenot 2000; Al-Amoudi and Latsis 2014; Diaz-Bone 2017: 83). Yet how exactly AFN construct their value conventions in order to achieve "compromises" (Boltanski and Thévenot 2006: 9) between conflicting value conventions, is still underexplored. Nor is it clear how AFN in general build value conventions, in particular if they avoid standardizing relevant criteria. In networks such as the solidarity economy, it is often stated that a fundamental goal is organizing the economy "not on the basis of profit", but on "relationships" and "social justice" (Tavolo RES 2010); yet little is known about how such distancing from mainstream businesses - from quality to "relations" works in practice. Is for instance the simple inclusion of small farmers enough to demonstrate "social justice", or are farmers expected to consequently repudiate profits? The article argues that this is no easy task for the actors involved, and the requirement to demonstrate "social justice" can lead to tensions to the extent that this conflicts with business motives.

This article discusses how an organization of solidarity economy farmers, Le Galline Felici (LGF), deals with such tensions. The LGF represents the largest solidarity economy organization in Southern Italy and is quite unique among units supporting the solidarity economy, perhaps also in wider Europe, not only because of its size (35 farms and processing units in 2018), but also because over the years it expanded its contacts so as to be capable of exporting almost half of its production to other European Union (EU) countries. The analysis shows that far from expecting farmers to renounce profits, a major promise from the organization to its members is that of facilitating the economic survival of as many small producers as possible. Nevertheless, LGF members acknowledge that distancing themselves from businesses pursuing profits represents a central valuation 
criterion in the eyes of the critical consumers engaged in solidarity economy networks. Such distancing is in no way standardized, for instance by formally requiring adherents to renounce part of their profits. Instead, distancing works through verifiable stories about concrete actions such as responding to increasing demand and customer numbers by inviting more producers into the network rather than through price or production increases. Such stories then circulate among consumer groups, and consumers can visit farmers and check these stories for themselves. Nonetheless, such distancing is open to debate and the relative discretion that the LGF enjoys in how to distance itself from the conventional system at the same time represents a gray area that can lead to tensions with consumers.

The empirical material comes from fieldwork research carried out by the author on several producer initiatives or organizations (in alternative and conventional agriculture), in Sicily in 2014. The author carried out in-depth semi-structured interviews with 27 farmers in the Catania and Syracuse area; out of these, ten had joined LGF, the farmers' organization adhering to the solidarity economy. Data from the interviews was corroborated with various documents collected during fieldwork, from the marketing documentation of conventional agriculture organizations and initiatives, to the membership forms, media interviews, and other statements made by actors in solidarity economy organizations in Sicily and Italy. The reason for selecting Sicily is that most "concentration" around retailers and wholesalers took place fairly recently - in the 2000s - something that facilitates the study of how the consolidation of retailer and wholesaler power in value chains impacts on small farmers and their approaches to constructing the value of their products. The strategy used during fieldwork was comparing how producers in both areas (AFN and conventional agriculture) deal with the demands and challenges associated with the aggregation of lands and in commodity chains around private or national certification standards.

\section{Valuation in Sicilian agriculture: From industrial to domestic and civic conventions}

Sicily's agriculture was a late case of what Wallerstein called European "commercial agriculture" (Wallerstein 1972), seeing throughout the eighteenth and nineteenth centuries the growth and expansion of grain, wine, and - from the nineteenth century onward - citrus fruit production due to increasing integration with world markets (Lupo 1987). By the end of the nineteenth century, Sicily was the largest citrus fruit exporter in the world, producing fruit for distant markets in North America, Northern Europe, and Eastern Europe (including Russia). The twentieth century brought a long period of decline, marked partly by the rise of ever more exporting regions in the world - from South America and Africa to the Mediterranean basin - and 
partly by an explosion of production costs since the 1980s, offsetting whatever benefits citrus fruit producers might have had due to the Common Market and later EU taxes on imports. These rising production costs are partly due to tax increases, and partly due to Italy's historical inability to redress irrigation systems in the area, causing high irrigation costs (see d'Amaro 2011 for a historical overview of the problem, pushing most producers in Western Sicily out of business).

The dominant production regime after World War Two, the "mercantile-industrial food regime", pushed Europe into the role of a major export region as the "emergence of a number of giant agro-food capitals" promoted the "industrialization of agriculture and elaboration of manufactured edible commodities sold by ever larger retail capitals" (Friedmann 2005: 240). Southern Europe was “passed by" (Marsden 2003) by the development of production regimes in Northern Europe (Arnalte-Alegre and Ortiz-Miranda 2013). Protectionism could not help local producers in this case compete again in world markets, especially since the 1980s, when the EU's "Southern" enlargement brought Italy's main competitors in the citrus sector into the Common Market. Furthermore, industrialization did not take off, with land ownership remaining highly fragmented and with a sector characterized not by "giant agro-food capitals", but by a myriad of producers and wholesalers.

This situation nevertheless began to change rapidly; prompted by the rise of retail chains and EU policies, important concentration processes swept over Southern Europe (Moragues-Faus 2016). In Sicily too local wholesalers initiated the creation of large producer organizations in the mid-2000s, in order to secure EU certifications (such as Indicazione geografica protetta [IGP]) and also for accessing EU funds to be invested in better warehousing, sorting, and transportation systems. The cause of this development includes the arrival of international retail chains due to the liberalization of retailing in Italy (Bonanno et al. 2014), and the strong financial and legislative support given by the EU and national authorities ever since the 1990s (Petriccione and Solazzo 2012). As a result, in the Catania and Syracuse provinces, provinces where most of Sicily's orange fruit production is located, important "conglomerates" emerged around only a few wholesalers: each collects products on surfaces of thousands of hectares, and each unites all production operations in the citrus commodity chain, from production to final delivery to the retailing company (Varga 2015).

Wholesalers in the Sicilian citrus sector not only have historically been the owners of warehousing, packaging, and transportation systems, but they have also played an important role in production by taking care of all harvesting operations long before the arrival of retail chains (for a historical overview see Lupo 1987). It should therefore 
not come as a surprise that they could become important partners for retail chains, and that farmers perceive them as gatekeepers of retailerled commodity chains. A development that interviewed farmers evoked most often as affecting the balance between wholesalers and producers is that ever since the mid-2000s wholesalers started buying up orange groves. Previously, wholesalers depended on goods supplied by producers, but with the arrival of retail chains, wholesalers could buy up land and invest in some production themselves as they have a secure market channel (the retail chains); this author's inquiry about the farms actually certified through the private certification standard GlobalGAP in Sicily found that these farms are all owned by the large wholesalers mentioned above. As a result of this development, from their profits wholesalers can cover the costs associated with running wholesaler facilities (storage and transportation); selling products bought from growers is no longer their only source of income.

Despite farmers' concern with growing wholesaler power, the wholesalers interviewed were not satisfied with the role of retailchain-suppliers and attempted to become retailers themselves or at least to depend less on sales to retail chains. As a consequence, they have become active in establishing their own brands and thus also engage in constructing the value of their products. In their efforts they downplay the industrial or commercial aspects of valuation in favor of emphasizing the domestic aspects of value. As an example, consider the growth of one wholesaler in the Catania area to become Sicily's largest oranges supplier over the last decade - selling to European retail chains production harvested on some 3,000 hectares of orange groves. R. (the corresponding brand's abbreviated name) - has made use since the brand's inception in 2005 of some of the notions that alternative food producers have considered particular to their production, in particular "place" and "health", combining the two notions in its slogan "R. oranges - naturally Sicilian". The marketing documentation describing the R. brand's creation explicitly sets out to downplay material aspects (approached negatively as "commodity") and emphasizes instead "domestic" aspects such as the importance of the product's origin: thus, the marketing plan was to

create the first brand of territorial quality regarding red oranges, capable of raising these in the perception of customers from simple commodity [English word used in the Italian original] to quality product with unique and inimitable qualities ... Make them perceive it as an excellent and unique brand and inform them about the specific organoleptic qualities and the environmental and territorial causes guaranteeing this result. (Club Dirigenti Marketing 2008)

Confirmation of these claims of "domestic" quality nevertheless comes in terms of industry quality standards: the private certification standards GlobalGAP and British Retail Consortium, with extensive documentation presented on R. websites. Thus, even though a 
European Commission documentation (2006) on GlobalGAP criticizes it for being virtually invisible to end consumers, it is intended to convince customers - from suppliers to large retailers and end consumers - of the quality and safety of production, and through large retailers also reaches consumers; furthermore, $\mathrm{R}$. explicitly uses the certifying documentation to substantiate its claims about the value of the product. GlobalGAP in principle allows actors in conventional agriculture to valuate production in terms bearing a certain resemblance to those of alternative producers - using such "domestic" aspects of localism, health, and supply chain transparency to demonstrate value. Yet it is largely silent over "civic" aspects such as the inclusion of smaller producers and the impact of production on workforce and disadvantaged social groups. Against this background the farms discussed below have taken a different approach to proving the value of their products: by practicing principles of the solidarity economy and circulating stories of their involvement in it, these farms communicate to select consumer groups in Northern Italy and more recently also in France and Belgium that their production is healthier, more ethical, and more transparent than mainstream products.

Most of the ten farms that set up LGF - the main producer group to coalesce in Sicily and more broadly in Southern Italy around ideas of the solidarity economy - had switched to organic farming in the 1990 s, or had practiced organic farming since their establishment in the 1980s, that is long before the constitution of LGF in the 2000s. Only three units had practiced organic farming out of environmentalist convictions, and the seven other viewed organic farming in instrumental terms: they hoped that organic certification might allow them to increase prices while guaranteeing market access. They hoped that certification could enable them to make claims about the healthpreserving benefits of their production that other farms could not make. By the early 2000s most LGF farmers came to consider organic certification as problematic - and the LGF founder and president even demonstratively gave up certification - which generally as a strategy was bringing limited to no results for reasons of being open to large agribusinesses and hardly trustworthy. In interviews LGF members expressed doubts about the effectiveness of controls and reported how the extent of controls in their cases depended on the company undertaking organic certification. Thus, they claimed that while some inspectors working for organic certification companies might indeed go to the field and take soil probes, most would simply look through accounting books and check whether purchased (and not necessarily also used) inputs corresponded to organic requirements. With organic certification in principle also available to large agribusinesses, small farmers needed other ways of proving the value of their products.

According to LGF members, by the 2000s the "price-cost squeeze" had made their farms' situation so dire that they were considering 
abandoning farming altogether. One farmer took a workforce reconversion course allowing him to learn how to use a computer and the internet, assembled a list of 240 GAS consumer groups' email addresses in Northern and Central Italy, and asked these for help. Solidarity Purchase Groups (GAS) are groups of consumers in Italy that coordinate efforts to supply themselves with certain goods usually basic food staples - by avoiding large corporate actors such as retail chains. Instead, they prefer buying products from small farmers, usually in their own communities. Similar forms of "alternative food provisioning” (Grasseni 2014: 179) also exist in other countries, for instance, in France as Associations for the Preservation of Peasant Agriculture (AMAPS), community supported agriculture in the United States and elsewhere in the world, as well as the Transition movement in Ireland and in the United Kingdom. 1

The corresponding response from Northern Italian GAS was so positive that it allowed the farmer to draw 14 others into a consortium (this was the official birth date of LGF), and 15 more as future or "training" members. Following the lead and ideas of Northern Italian GAS, participating farmers developed their activities around the concept of the solidarity economy, on one hand allowing them to prove their "alterity" without relying on certifying institutions, and on the other hand allowing them to pool resources and access "mutual help networks".

By 2015 LGF had reached 25 members, up from an initial group of 10 producers in 2008, and 40 aspiring members were hoping to join the organization. In 2018 it had 35 members and 30 permanent employees. While initially - throughout the 2000s - members were predominantly shipping to some 200 GAS in Italy, by 2015 almost 40 percent of production (some 1,000 tons, and $€ 1.4$ million in revenues) went to purchase groups in Belgium and France. In France, groups buying predominantly LGF products appeared around 2012 in several

\footnotetext{
${ }^{1}$ Grasseni offers the following definition of GAS (2014: 180): "They are grassroots aggregations of consumers who involve producers in direct and collective transactions. GAS mainly organize food provisioning but, increasingly, non-food provisioning too (of clothes, shoes, cleaning materials, and in some experimental cases also electricity, car insurance, dental care, and telecommunication).” GAS strictly guard the boundaries of solidarity economy networks, something evident in the treatment of mainstream businesses. While companies such as Lindt, Philips, Peugeot, and Coop were admitted to the "Do the right thing" Fair in Milan as early as 2011, the major "critical consumption" fair in Italy, their participation in GAS networks and fairs is unheard of. Furthermore, the Milan event was faced with severe criticism from leading GAS representatives; in the words of a member of Tavolo RES (the main coordinating body of solidarity economy groups in Italy): "[such events represent] a loss of collective critical capacity, facilitating the colonization and cooptation through the capitalist market, bringing the risk of neutralizing the solidarity economy movement. This is what the experience of such national fairs represents." (Khorakhanè Center in Lecco's website at http:// www.esserevento.it/? $\mathrm{p}=6083$, accessed 6 April 2017).
} 
regions (Paris, Lille, Languedoc-Roussillon, and Hautes Alpes; the author interviewed the initiators of the group in Lille). Six associations were buying LGF products in Hautes Alpes, claiming to be distributing these to some 1,700 families or 10 percent of the department's population; ${ }^{2}$ Corto, the largest of the groups in Paris, claimed in 2014 to be distributing LGF products to some 700 families. $^{3}$

\section{Building value by proving attachment to solidarity economy principles}

This section discusses how LGF members claim to prove the value of their products, in ways that part with mainstream business and that relate to the notion of civic conventions. It identifies three components in LGF's practice of proving value. First, there is a declarative component, emphasizing support for the principles of the solidarity economy and the distance to standard business actors; it consists of issuing statements that the LFG shares the same principles as the larger solidarity economy network. Second, there is a concern with actually treating other actors - from competitors to workers and customers - in ways that do not square with mainstream business motivations. Third, consumers are invited to check, but also to disseminate and debate LGF actions.

\section{Practicing principles of the solidarity economy}

LGF's expansion relies on reaching out to GAS in the solidarity economy and convincing these of the producers' attachment to solidarity economy principles, most importantly to the idea of rejecting standard business approaches, rejecting competition in favor of cooperative relations of mutual help among producers, between producers and consumers, and between producers and the wider local community. The need to demonstrate and restate adherence to guiding principles is of crucial importance for constructing notions of value. The LGF members' main strategy for doing so is creating, circulating, and inviting consumers to check stories about the producers' attachment to solidarity economy principles. LGF members - like small farmers more generally - struggle with the task of reaching out to consumers and convincing these of the value of their products. By entering solidarity economy networks, producers gain access to a venue in which they can shift notions of value from a product's

2 See for instance the following account on the main GAS website, http:// www.economiasolidale.net/content/partire-dalle-arance (accessed December 15, 2016).

3 See for instance the reports on the following webpages, including Corto's website http://www.volontariperlosviluppo.it/index.php?option=com content\&view=article \&id=3016\%3 Aun-arancia-tira-l-altra-fino-a-parigi\&catid=980\&Itemid=200419; http://www.corto.ouvaton.org/ wordpress/ (accessed 15 December 2016). 
material properties to "civic" aspects, including the ethics of production and the deliberative practices that make production possible. In the words of one of the LGF founders:

I am not interested in oranges ... but in spreading good practices, together with GAS ... We ask customers: Do you want to pay the lowest possible price for oranges or do you want to spend a fair amount that prevents the exploitation of those doing the work? We use a company confiscated from the Mafia in order to ship products to the North. We want labor laws to be respected. Truck drivers need to keep legal schedules and receive a just pay. It's obvious that transport will then be more expensive. Our customers pay three cents more per kilogram for spreading good practice ... Our customers are those that agree with us on this system of creating prices.

Thus, the first way of proving value in the sense of attachment to solidarity economy values is declarative, that is by issuing statements that the LFG shares the same principles as the larger solidarity economy network and by joining and signing relevant documents and charters.

In practice, reasons why individual members joined LGF vary widely, ranging from those that saw in LGF a way of advancing wider societal goals to those that joined LGF for ensuring the survival of their enterprises. Thus, one LGF member confessed during fieldwork that he joined LGF in order to receive access to a new "market channel", as attempts to sell to large retail chains proved fruitless; even though his land had been organically certified since the 1990s, "the main reason for seeking [organic] certification was [gaining] access to EU subventions". Yet organic certification proved deeply problematic, despite the influx of EU money: "many people work organically, for subventions, and only a few of them also sell [their products]. But the product is nevertheless there, so that prices decrease to levels comparable to conventional production" (interview 3, Francofonte, February 2014). On his admission form to the Southern Italian solidarity economy network he stated that "my objective is that of leading the enterprise to [having] a positive balance with a decent income" (document in author's archive). Others stressed that selling through LGF is the only legal outlet for their production, being too small to qualify for other channels or too poor to make the investments that would allow them to receive permissions to legally act as direct sellers, in particular if selling processed products such as cheese: "It annoys me that I could be proud of my profession, allowing me to feed my three children, but instead I have to hide", says a 42year old landless producer, owning 27 goats he grazes on abandoned, mountainous terrain (interviews 2 and 11, Catania, March 2014). In contrast, another LGF farmer stressed that his $€ 35,000$ yearly income, not profit, barely covers subsistence needs but that he is satisfied with only having so much and barely more, "if things go well" and he 
indeed reaches that yearly income (interview 22, Paterno, March 2014).

Yet even when driven by profitability considerations and the desire to ensure the survival of the farm and "decent incomes", other members nevertheless stress the non-economic, affective considerations that prevent them from giving up farming: "People sell their farms, as product prices are too low. But it is the children that sell, because for their parents the affective bond with the trees is far too powerful. I, for example, know each tree, each branch; these trees mean a lot to me. But for children the reasoning is that this tree costs me $€ 50$, this one another $€ 50$, and so on, there is no affective bond. And this [reasoning] is what the big businesses profit from when they buy up the land" (interview 1, Augusta, March 2014).

\section{Relationships with competitors, suppliers, and employees}

The second way of proving value consists of showing that LGF's choice of partners in production defies standard business motivations: other producers are not competitors but potential partners. Furthermore, suppliers are chosen not on price considerations, but on the basis of trying to help out enterprises that serve higher community goals. What is critical about these actions is that they translate into stories about LGF that reach the widest circulation throughout the solidarity economy network and in particular among GAS, as outlined below. In this way, LGF not only builds a reputation that proves the value of its products, but at times can even mobilize financial support of the wider GAS network to help LGF survive the more difficult moments of its existence.

LGF members emphasize that a central element in how they justify the value of their products by proving attachment to principles of the solidarity economy is how LGF treats potential competitors (other, non-affiliated small farmers). Instead of opposing the access of other farmers to LGF ranks and profits, the group lets these join after a reviewing process. During this process LGF checks the employment conditions of hired seasonal workers and whether farmers respect principles of organic farming. Organic certification was not a requirement, as instead LGF members checked for themselves whether production was indeed organic by visiting the farms of aspiring producers. 4

\footnotetext{
4 Two studies of LGF (BA and MA theses) suggest that this type of informal certification indeed took place before and after the 2014 fieldwork round for this article (Balcazar 2013; Steggerda 2016). By 2017 however LGF producers had all returned to formal organic certification in order to maintain within its customer base certified stores, restaurants, and cooperatives that needed to prove the organic certification of their supply chain.
} 
The other important component of the reviewing process is making sure that the farm's production is stable enough to deal with GAS orders. Other farms or economic units initially joined the Arcipelago Siqillyàh association, an organization initiated by LGF for aspiring members (today the association is no longer active, and aspiring LGF members - so-called pulcini - simply approach LGF directly in order to undergo the reviewing process; actually joining LGF within one year is considered fast and exceptional. This story about treating other producers not as competitors but as potential partners is eagerly circulated by LGF members and Tavolo RES, emphasizing in particular how the initiative to enlarge LGF came not from producers, but from solidarity GAS that in 2009 held their eighth national congress in Sicily, following a call from LGF. In the words of an LGF founder (interview 1, Augusta, February 2014): "And here, in a plenary assembly, someone asked: 'Very good, LGF! But now what are you going to make of the credibility and reliability you've conquered, are you going to keep it for yourselves? Or are you going to use it to make everybody else grow too?'”

Another way of showing their support for the solidarity economy was to allow "social cooperatives" into LGF, and again circulating this story about inclusion among solidarity networks, including those in France and Belgium. Social cooperatives are economic units set up by state authorities in Italy to provide various disadvantaged groups with employment; many GAS in the North emphasize the importance of placing orders with such economic units in order to support them (Tavolo RES 2010). LGF took up two such social cooperatives representing processing units operating within state penitentiaries and employing convicts; by 2017 two more had joined LGF. One LGF founding member recalled about one processing unit that:

In 2008 it was about to close down as it had no orders, so we sent an email to all recipients [in the GAS-groups list] inviting them to place orders with payments in advance. After 15 minutes there was a first invoice for $€ 3,200$, in 15 days we collected $€ 17,000$ and production went off again. Today there is a 30 percent increase in turnover, and the number of employed convicts went from 4 to 32 , and they also took over the prison's kitchen! (interview 1, Augusta, February 2014)

In 2015 the situation of the processing unit had again worsened, with employees down to eight and no funds to buy raw materials. Help was again mobilized through LGF and its GAS network, mobilizing what in the meantime had become an international customer base, with associations buying up LGF products in advance in Italy, France, and Belgium.

Again attempting to prove its adherence to principles of the solidarity economy, LGF members chose a transport company (Riela) 
that the state had confiscated from organized crime networks. In 2009-12 LGF relied exclusively on Riela for shipping products, in partnership with Italy's Agency for Confiscated Goods. LGF members emphasized that unlike other companies in the sector, Riela respected the drivers' rights to rest at certain time intervals, and paid drivers legal wages. In 2012, Riela lost a lorry in an accident together with the entire freight (destined for GAS groups, as LGF was Riela's only customer) and further threatening LGF with failure to deliver its products on time. In response, LGF bought another lorry with money from GAS groups; but the Agency nevertheless declared Riela's bankruptcy that year, and LGF had to pay back from its own means the money spent on the lorry. A strike wave of other transport companies - accompanied by road blocks - brought further losses to LGF that year.

At the same time the case also shows a key feature of the solidarity economy, and the episode is remembered by both LGF members as well as some of the GAS groups involved as another chance of demonstrating adherence to guiding principles, such as "the possibility of organizing the economy on the basis of relationships, not profit" (Tavolo RES 2010: 6), relationships understood in the sense of mutual help. Thus, the fact that LGF asked consumer groups for help in buying a truck for Riela shows that the relationship between GAS groups and producer organizations consists of more than the exchange of a commodity, at times representing something that can be mobilized to help sustain producers. The case is not unique, as Grasseni (2014: 183-4) reports several similar cases taking place in Italy, with probably the most important one being the case of the Tomasoni family diary, saved from bankruptcy by a network of 200 GAS. GAS thus show one way in which social justice can be made to mean more than offering producers a higher price. Similarly, in 2014 LGF again mobilized GAS networks to financially support it by making payments of some $€ 60,000.5$

These "mutual help" relationships are at times more important as a tool for valuation than other perspectives, such as "domestic" conventions regarding the place and proximity of the products. Even though many GAS founders depict GAS as originating in "food scares" and out of concern for the impact of industrial food production on health and the environment, in the case of the North-South partnership GAS members reordered their criteria for valuation, preferring ideas of justice to producers over ideas of fair miles (Tavolo RES 2010, 2013). They accepted Sicilian producers as their suppliers in order to help farmers in one of their country's worst-off regions, even though transport routes from Sicily to partner GAS in Northern Italy

5 http://www.ecoista.it/interviste/galline-felici-consorzio-servizio-bene-comune/, accessed 25 March 2017. 
total at least 1,200 kilometers (one way only). In this case GAS discarded the importance of " $\mathrm{km} \mathrm{0"-ideas} \mathrm{(a} \mathrm{rough} \mathrm{equivalent} \mathrm{of} \mathrm{"fair}$ miles", emphasizing producer proximity to consumers in order to minimize the environmental impact of transportation).

LGF also attempts to transform the treatment of employed labor into a key area of valuation and constructing alterity. Thus, one initiative of LGF producers was to make transparent all harvesting operations carried out on their properties, by employing the same workers and allowing GAS members to meet these. A further initiative consists of the idea of giving workers a voice in the production process, through the creation of RisOrti Migranti in 2013, an initiative of recuperating abandoned land and then offering it to immigrant workers to develop it for agricultural production; the workers would then become members of one cooperative, together with the consumers purchasing their products (such consumers were contacted mostly via the GAS network); at the time of the fieldwork (early 2014), two immigrants were working on the project and supplying some 15 families with fresh vegetables. 6 While the initiative was far from the intended size, in terms of valuation the gains were clear for the LGF consortium that had helped bring the idea to life: heavily circulated on GAS websites, the invitation issued by the LGF to GAS groups to become involved in the cooperative by placing orders in advance signaled yet another way in which LGF members demonstrated support for solidarity economy ideas of seeing value not in the material properties of the products, but in the relationships involved in production.

\section{Circulating, checking, and debating LGF stories}

LGF members invite consumers to check these stories, visit production sites and social cooperatives, and spend time at these locations, following and sometimes even getting involved in the various production steps (mostly harvesting). So-called consumer group "referents" visit and spend time on LGF locations; as observed during fieldwork, even "referents" from France paid LGF farms yearly visits. It is important that these "referents" represent consumers sharing solidarity economy ideas; other, non-solidarity consumers that visited one LGF farm during fieldwork were appalled by the farm's small size (one hectare), for them a reason for concern and for refusing in the end to engage with LGF as customers: "We're afraid of how small this place is, maybe the harvest is so small that they'd only offer us the worst products" (interview with customers, Augusta, March 2014). Of course, consumers without agricultural knowledge even if sharing solidarity economy ideas cannot make judgments about how healthy

6 The project's website http://www.gaslife.it/RISORTI-MIGRANTI, accessed 20 September 2017. 
or environmentally friendly production methods are simply by looking at the plants and cultivation areas. And the issue of fraud is looming for instance in the form of organics-certified producers selling uncertified products (acquired from uncertified producers, often without legal forms), again a possibility that consumers cannot eliminate simply by looking at what they buy. During fieldwork, one producer accused an LGF member of doing precisely this: selling goods produced by uncertified neighbors for a healthy difference. However, if farmers shift notions of value from a product's material properties to the extent and forms of producer involvement in the solidarity economy, the presence of consumers on production sites becomes more meaningful, as consumers can debate and value (or not) the actions and choices of producers.

Most importantly, consumers are invited to disseminate, but also debate the actions of LGF. Given that most GAS communicate online, initially via mailing lists and increasingly via forums and dedicated websites, these online communication channels constitute the primary route for LGF's stories or calls for participation in its actions. This type of communication is even more accessible for LGF in the case of those French and Belgian GAS that emerged precisely in order to buy LGF products. The oldest and most active of them, the France-based groups Givrés d'Oranges, Corto and Court-Jus even use the Italian term "GAS" to refer to themselves (instead of the French AMAP), and circulate among these groups not only the story and calls of LGF, but also the reports of each of these groups' visits to inspect LGF farms. ${ }^{7}$

LGF's decision to serve consumer groups abroad was met with criticism by GAS members in Italy, in particular because LGF sought to respond to the largest orders first, in practice meaning that priority would be at times given to orders from abroad. In the words of LGF members, the criticism was formulated as follows: "You are meeting the demands of new clients and cannot respond to the demands of old customers?" This criticism implied that LGF was failing - in the context of this particular decision - to demonstrate its distance from

\footnotetext{
7 These reports vary greatly in terms of length, technicality, and issues covered, but in general hardly discuss issues of quality or taste, and instead tend to reflect on the hardship and poverty associated with agriculture in Sicily. The reports by Givrés d'Oranges, written by two teachers from Lille, are the most detailed - so detailed that they also reflect on meeting the author of the present study - and are also the ones that are most concerned with the political aspects of consumption: the rise of mass, standardized consumption and its role in destroying "local realities" is illustrated in the 2014 report with a quote from Pier Paolo Passolini stating that the "consumption society" succeeded where "fascism failed", and LGF actions are perceived as parts of a political movement aiming to curb or redress the excesses of mass consumption. Members of Givrés d'Oranges see themselves as part and parcel of the same movement. (The report is available at https:// givresdoranges.files.wordpress.com/2014/05/nouvelles-de-la-sicile-de-ses-agrumes-etdautres-choses-encore.pdf, accessed 26 October 2017).
} 
mainstream businesses. LGF seized the opportunity and answered to criticism by restating the values that -in the LGF producers' perspective - had cemented previous deals, namely support of those involved in production: as more farmers turned to LGF for help, they took up the bigger orders for reasons of helping out as many producers as possible: "This allowed many more producers to 'enter the circle' and escape the game of intermediaries, and enlarge their own cultural and human horizons; thanks, GAS!" In the end, there were no reports about Italian GAS groups abandoning the purchase of LGF products.

By turning the debate from one over whose orders should be served first, into one over enlarging the base of small producers that can benefit from orders, LGF members created another verifiable story about upholding the principles of the solidarity economy, and strengthened their reputation within solidarity networks. The debate around LGF's expansion abroad hints at the possibility that "profit motivation" and its repudiation are debatable concepts, and on this occasion LGF won the debate over its actions by presenting its expansion as an opportunity to grow in order to allow more producers to join its ranks.

\section{Discussion}

Numerous and varied initiatives over the last decades have attempted to carve out niches of alterity vis-à-vis large agribusinesses and expanding retail chains. From ideas about direct agricultural markets and organic farming to Fairtrade, community supported agriculture, food justice, and food sovereignty movements, these initiatives can be envisaged as struggles over the valuation of products not just as a reflection of supply and demand, but of quality, origin, the production's impact on communities, public health, environment, and the livelihood of the employed labor force.

The conventional sector has demonstrated that it can appropriate partly or entirely many of the concepts developed for demarcating alterity niches in times of multiplying food scares and consumer anxieties. From entering organic farming in the 1990s to developing certification schemes since the 2000s, agribusinesses and retail chains have appropriated concepts such as organic, quality, transparency, or locality (Sonnino and Marsden 2006). Alternatively, as exemplified by the GlobalGAP certification scheme, they have come up with their own concepts for demonstrating to "critical consumers" (Norris 1999) their interest in producers' welfare as well as supply chain transparency or traceability. Conventional businesses adhering to the GlobalGAP standard became part of "a system of production that, if not purely organic in origin, was at least, via audit, claiming the two key desirable consumer attributes of organics: food safety and environmental sustainability" (Campbell 2005: 4). Conventional agribusinesses thus 
more or less continuously redefined the boundaries between mainstream and the alternatives to it, justifying concerns about the extent to which alternatives to the conventional sector can endure and even about the extent to which they are truly desirable. As summarized in Goodman and Goodman (2009), the emphasis on localism in many AFN turned a blind eye on exploitative production relations within these networks, and on the exclusive character they developed, being hardly accessible to poorer consumers and small producers.

Not necessarily claiming to solve all of these problems, more recent "food movements" have increasingly changed the grounds for valuing products in AFN. The value convention emphasizing product quality and consumer wants changed into a value convention about the nature of relations involved in production, giving more weight to producers and reflecting on exploitative relationships in farms and communities. Fairtrade was a forerunner in this respect that helped show how even though "private regulatory schemes [such as GlobalGAP] have purportedly progressive goals, they undermine these goals by failing to engage alternative patterns of economic coordination" (Raynolds 2002: 402). While Fairtrade welcomed the involvement of agribusinesses such as processors, solidarity economy fiercely opposes any involvement of agribusinesses or retail chains in its structures. It too engages in valuation attempts that build on the assertion that "the progressive potential of alternative commodity networks derives from the persistent questioning of traditional business mentalities and the promotion of alternative qualifications" (Raynolds 2002: 402).

The change in value conventions - from the "quality" of products to the nature of "relations" involved in production - is anything but seamless; such conventions hardly ever completely abolish each other, and to the extent they coexist, they might provoke tensions among the actors involved. The change in value conventions together with the tensions occasionally surrounding them speak to the literature on valuation and to its preoccupation with exploring the practical struggles of accommodating different value registers or conventions (Helgesson and Kjellberg 2013). It invites questions about how - in the absence of the certification schemes and standardization underpinning notions of "quality" - such distinct notions of value can work in practice; how producers can actually demonstrate to consumers the "civic" value of their products; and whether and how the emphasis on "relations" can do without conventions regarding prices, enterprise growth, and profit.

This article showed how the LGF consortium achieved the shift to civic conventions by circulating stories of how it defies standard business motivation. It thus relied on a discursive device substantiating the consortium's adherence to solidarity economy principles of mutual help and cooperation rather than competitive relations. Such valuation is at times plagued by contradictions; what is not standardized is open 
for interpretation and consumers have questioned LGF's commitment to solidarity as soon as LGF became economically successful. In other words, demonstrating to consumers the seriousness of its commitment to the conventions of the solidarity economy, rather than to the conventions dominating the sphere of business, is a difficult task. Handling it depended on LGF's capacity to argue that even breaks in the script - such as the appearance of economic success, profit, and growth - can be accommodated with initial, solidarity economy goals. And this in turn succeeded, because at times LGF's stories are more than that: they are common experiences, shared by producers and consumers and cementing LGF's credibility. Thus, on occasions such as when LGF requested help to save its processing cooperative, these stories became more than narratives as they encourage the participation of consumers, and thus developed from simple stories into common producer-consumer experiences in which to ground the value of products.

\section{Acknowledgment}

The author would like to thank the editorial board and two anonymous reviewers for their constructive comments that have helped improve this manuscript. The author also extends his thanks to the Fritz Thyssen Foundation that covered two months of fieldwork in early 2014.

\section{References}

Al-Amoudi, Ismael, and John Latsis. 2014. "The Arbitrariness and Normativity of Social Conventions." The British Journal of Sociology 65(2): 358-378.

Arnalte-Alegre, Eladio, and Dionisio Ortiz-Miranda. 2013. "The 'Southern Model' of European Agriculture Revisited: Continuities and Dynamics." In Agriculture in Mediterranean Europe: Between Old and New Paradigms, edited by Eladio Arnalte-Alegre and Dionisio Ortiz-Miranda, 37-74. Bingley: Emerald.

Balcazar, Ramón Morales. 2013. "Les réseaux d'économie solidaire, une alternative viable au systeme agricole modernisé?” Unpublished MA Thesis. Paris-Sud University.

Boltanski, Luc and Arnaud Esquerre. 2014. "La 'collection', une forme neuve du capitalisme la mise en valeur économique du passé et ses effets.” Les Temps Modernes 679: 5-72.

Boltanski, Luc, and Laurent Thévenot. 1999. "The Sociology of Critical Capacity." European Journal of Social Theory 2(3): 359-377.

- 2000. "The Reality of Moral Expectations: A Sociology of Situated Judgement. Philosophical Explorations 3(3): 208-231. 
2006. On Justification: Economies of Worth. Princeton, NJ: Princeton University Press.

Bonanno, Alessandro, Elena Castellari, and Paolo Sckokai. 2014. "Trade Liberalization and Food Retail Structure: The Italian Case." AIEAA, Italian Association of Agricultural and Applied Economics, 3rd conference, Alghero, June.

Brunori, Gianluca, Adanella Rossi, and Vanessa Malandrin. 2011. "CoProducing Transition: Innovation Processes in Farms Adhering to Solidarity-Based Purchase Groups (GAS) in Tuscany, Italy. International Journal of Sociology of Agriculture and Food 18(1): 28-53.

Callon, Michel, Cécile Méadel, and Vololona Rabeharisoa. 2002. "The Economy of Qualities.” Economy and Society 31(2): 194-217.

Campbell, Hugh. "The rise and rise of EurepGAP: European (re) invention of colonial food relations." International Journal of Sociology of Agriculture and Food 13, no. 2 (2005): 6-19.

Club Dirigenti Marketing. 2008. "Quaderni sui convegni promossi dal Club Dirigenti Marketing.” Club Dirigenti Marketing. http://www.clubdirigentimarketing.org/index.php? option=com_content\&view=article\&id=19:i-quaderni-sui-convegnipromossi-dal-club-dirigenti-marketing $\&$ catid $=25 \&$ Itemid $=118$, accessed 20 September 2018.

D'Amaro, Francesco. 2011. "Il mercato dell'acqua. Politica, istituzioni e conflitti nel distretto agrumicolo di Bagheria (XX sec.)." Meridiana 71: 271-291.

Diaz-Bone, Rainer. 2017. "Discourses, Conventions, and Critique Perspectives of the Institutional Approach of the Economics of Convention." Historical Social Research/Historische Sozialforschung 42(3): 79-96.

European Commission. 2006. "EurepGAP.” European Commission Research Directorate. http://ec.europa.eu/agriculture/quality/certification/docs/ case5_en.pdf, accessed 20 September 2018.

Friedmann, Harriet. 2005. "From Colonialism to Green Capitalism: Social Movements and Emergence of Food Regimes." In New Directions in the Sociology of Global Development, edited by Frederick H. Buttel and Philip McMichael, 227-264. Amsterdam: Elsevier.

Gereffi, Gary. 2014. "Global value chains in a post-Washington Consensus world." Review of International Political Economy 21(1): 9-37.

Goodman, David, and Michael Goodman. 2009. "Alternative Food Networks.” In International Encyclopedia of Human Geography, 3, edited by Rob Kitchin and Nigel Thrift, 208-220. Amsterdam: Elsevier.

Goodman, David, E. Melanie DuPuis, and Michael K. Goodman. (2012). Alternative Food Networks: Knowledge, Practice, and Politics. London and New York: Routledge.

Grasseni, Cristina. 2014. "Seeds of trust. Italy's Gruppi di Acquisto Solidale (Solidarity Purchase Groups).” Journal of Political Ecology 21(1): 178192. 
Helgesson, Claes-Fredrik, and Hans Kjellberg. 2013. "Introduction: values and valuations in market practice." Journal of Cultural Economy 6(4): 361-369.

Holt Giménez, Eric and Annie Shattuck. 2011. "Food crises, food regimes and food movements: rumblings of reform or tides of transformation?" Journal of Peasant Studies 38(1): 109-144.

Kjellberg, Hans, and Alexandre Mallard et al. 2013. "Valuation studies? Our collective two cents." Valuation Studies 1(1): 11-30.

Lamont, Michèle, and Laurent Thévenot. (2000). "Introduction. Toward a Renewed Comparative Cultural Sociology." In Rethinking Comparative Cultural Sociology. Repertoires of Evaluation in France and the United States, edited by Michèle Lamont and Laurent Thévenot, 1-22. Cambridge: Cambridge University Press.

Lee, Joonkoo, Gary Gereffi, and Janet Beauvais. 2012. "Global value chains and agrifood standards: challenges and possibilities for smallholders in developing countries." Proceedings of the National Academy of Sciences 109(31): 12326-12331.

Lupo, Salvatore. 1987. "Tra società locale e commercio a lunga distanza: la vicenda degli agrumi siciliani.” Meridiana 1: 81-112.

Marsden, Terry. 2003. The Condition of Rural Sustainability. Assen: Uitgeverij Van Gorcum.

Marsden, Terry, and Adrian Morley (eds.). 2014. Sustainable Food Systems: Building a New Paradigm. London and New York: Routledge.

Moragues-Faus, Ana. 2016. "Revisiting Food Studies from a Political Ecology Perspective: Lessons from Mediterranean Agri-Food Systems." In Agriculture, Environment and Development. International Perspectives on Water, Land and Politics, edited by Antonio AR Loris, 59-90. Basingstoke: Palgrave Macmillan.

Norris, Pippa (ed.). 1999. Critical Citizens: Global Support for Democratic Government. Oxford: Oxford University Press.

Petriccione, Gaetana, and Roberto Solazzo. 2012. "Le organizzazioni dei produttori nell'agricoltura italiana.” Agriregionieuropa 8: 18-22.

Raynolds, Laura T. 2002. "Consumer/producer links in fair trade coffee networks." Sociologia ruralis 42(4): 404-424.

Renting, Henk, Markus Schermer, and Adanella Rossi. 2012. "Building Food Democracy: Exploring Civic Food Networks and Newly Emerging Forms of Food Citizenship." International Journal of Sociology of Agriculture and Food 19(3): 289-307.

RES (Tavolo per la Rete italiana die Economia Solidale). 2010. Il capitale delle relazioni. Milan: Altreconomia.

RES (Tavolo per la Rete italiana die Economia Solidale). 2013. Un'economia nuova, dai Gas alla zeta. Milan: Altreconomia.

Sassatelli, Roberta. 2015. "Consumer culture, sustainability and a new vision of consumer sovereignty.” Sociologia Ruralis 55(4):483-496. 
Sonnino, Roberta, and Terry Marsden. 2006. "Beyond the divide: rethinking relationships between alternative and conventional food networks in Europe." Journal of Economic Geography 6(2): 181-199.

Steggerda, Michelle. 2016. "Co-evolution of Social Enterprises and Their Environment. A Multiple Case-Study of Puur Lokaal and Le Galline Felici." Unpublished BA thesis. Wageningen University.

van der Ploeg, Jan Douwe, Henk Renting, Gianluca Brunori, Karlheinz Knickel, Joe Mannion, Terry Marsden, Kees De Roest, Eduardo SevillaGuzmán, and Flaminia Ventura. 2000. "Rural development: from practices and policies towards theory." Sociologia Ruralis 40(4): 391-408.

Varga, Mihai. 2015. "Value chains or social capital? Producer organizations in the citrus fruit sector." International Journal of Sociology of Agriculture and Food 22(2): 85-103.

Vorley, Ben. 2007. Supermarkets and agri-food supply chains in Europe: partnership and protest. In Supermarkets and Agri-Food Supply Chains: Transformations in the Production and Consumption of Foods, edited by David Burch and Geoffrey Lawrence, Chap. 11. Cheltenham: Edward Elgar.

Wallerstein, Immanuel. 1972. "Three paths of national development in sixteenth-century Europe." Studies in Comparative International Development 7(2): 95-101.

Ward, Neil, Peter Jackson, Polly Russell, and Katy Wilkinson. 2008. "Productivism, post-productivism and european agricultural reform: the case of sugar.” Sociologia Ruralis 48(2):118-132.

Wilkinson, John. 1997. "A new paradigm for economic analysis? Recent convergences in French social science and an exploration of the convention theory approach, with a consideration of its applicability to the analysis of the agro-food system." Economy and Society 26(3): 305339.

Wilkinson, John. 2002. "The final foods industry and the changing face of the global agro-food system." Sociologia Ruralis 42(4): 329-346.

Zelizer, Viviana A. 1978 "Human values and the market: the case of life insurance and death in 19th-century America." American Journal of Sociology 84(3): 591-610.

Mihai Varga (PhD University of Amsterdam 2011) works as senior lecturer at the Freie Universität Berlin, Institute for East European Studies. His research focuses on market reforms and their politicaleconomic consequences. He has published on World Bank-inspired reforms, trade unions' responses to worker protests and austerity, and on the rise of right-wing forces following the financial crisis of 200708 . 